\title{
Danish multinational corporations in China: an evolutionary approach to internationalisation
}

\author{
Stine Jessen Haakonsson \\ Department of Business and Politics, \\ Porcelænshaven 24A, Ground floor, \\ 2000 Frederiksberg, Denmark \\ Email:sh.dbp@cbs.dk
}

\begin{abstract}
Multinational corporations (MNCs) strategise in a dynamic multi-polar world consisting of changing environments at home and abroad. They continuously face a new set of push- and pull-factors for internationalising activities. In recent decades, internationalisation has been reaching into emerging markets, which are significantly different from MNCs' traditional locations. As globalisation progresses, internationalisation increasingly involves exploitation strategies, i.e., offshoring of production; market access; and exploration strategies such as internationalisation of innovation. This article looks into how Danish MNCs have evolved into the Chinese economy, investigating the trajectories of how and when four Danish MNCs entered the Chinese economy and how the strategy patterns have emerged from cost reduction, to market access, and recently to innovation. Over 30 years, China has developed into an important hub for MNC offshoring of innovation. The four MNCs have changed the mandate of the Chinese innovation sites into global centres of excellence.
\end{abstract}

Keywords: multinational corporations; $\mathrm{MNCs}$; internationalisation; push- and pull-factors; Danish MNCs; Chinese economy; institutions; MNC trajectory; evolutionary approach; China.

Reference to this paper should be made as follows: Haakonsson, S.J. (2017) 'Danish multinational corporations in China: an evolutionary approach to internationalisation', Int. J. Multinational Corporation Strategy, Vol. 2, No. 1, pp.51-75.

Biographical notes: Stine Jessen Haakonsson is an Associate Professor at the Department of Business and Politics, Copenhagen Business School. She holds a $\mathrm{PhD}$ in Economic Geography from the University of Copenhagen and the Danish Institute for International Studies. Her research focuses on multinational corporations, global restructuring of innovation, global innovation networks, and the role of emerging market actors in this process. Recently, her focus has been on the globalisation of clean-tech sectors, pharmaceuticals, and bio-fuel.

\section{Introduction}

Over the past centuries, multinational corporations (MNCs) have emerged and increasingly engaged in internationalisation through trade; offshoring and foreign direct investments (FDIs); and outsourcing. Over the past three decades, this process has developed into a globalisation process integrating a range of locations as a result of a 
combination of changing location factors in the home and host countries and the increased possibilities for reorganising industries in general (Feenstra, 1998). In this globalisation process, MNCs are strategising in a dynamic multi-polar world consisting of changing environments at home and abroad. Hence, strategies are influenced by a combination of push- and pull-factors (Haakonsson et al., 2013). Push-factors drive a continuous process of further internationalisation for sustained competitiveness while pull-factors drive location decisions based on strategies for lowering costs, gaining market access, or accessing strategic assets such as innovation capabilities (Iammarino and McCann, 2013; Moncada-Paternò-Castello et al., 2011). Emerging market locations are attracting an increasing and considerable share of global FDI, although these locations have significantly different characteristics from MNCs' traditional locations (Costa et al., 2015). Over the past decades, Asia and in particular China has evolved into one of the most attractive locations for FDI and is today the majority single emerging market location for FDI (Jensen and Pedersen, 2011). The nature of investments has changed over time. Initially FDI into China related to outsourcing and offshoring of production in order to lower production costs. China was at that point seen as the main location for global manufacturing - the factory of the world. More recently, the Chinese economy has changed its attractiveness into increasingly becoming a market for products and a location for innovation and product development.

This article investigates the following research questions:

1 To what extent does MNCs' increased engagement in innovation activities in an emerging market follow certain trajectories?

2 How can these trajectories be explained by an evolutionary approach to internationalisation?

Moreover, the article looks into the extent to which Danish MNCs' offshoring to China has evolved in a certain pattern and whether changes in the institutional framework have impacted this pattern. Hence, the article contributes to the argument about the importance of evolutionary approaches to international business. By analysing Danish MNCs' internationalisation into China, the article furthers the understanding of the evolution of FDI engagements from offshoring of production (cost reduction), to market entry, and more recently to establishing research and development (R\&D) facilities in China. The evolutionary approach integrates the firm level perspective with the dynamics of the ownership advantages of Danish firms, i.e., the push-factors related to internationalisation as they are experienced by Danish MNCs, as well as an institutional perspective on China's evolution into an attractive location for FDI during the past three decades, i.e., the pull-factors. Taking on the push- and pull-factors allows for addressing the research gap between international business and economic geography as it allows for an understanding of how MNCs internationalisation into a given host location depends on location characteristics along with the MNCs' characteristics.

The relevance of this study lies in enhancing the ongoing debate linking the international business and economic geography literatures through focusing on the evolutionary drivers of internationalisation with an empirical perspective on Danish MNCs and their engagement in China. The focus will be on the drivers of internationalisation on each level and the interrelationship between the two. Looking into the entry of four leading MNCs from production to market to innovation in China and how this process links to the development of the Chinese institutional framework, this 
article illustrates the evolutionary dynamics of MNCs evolving into global innovation networks in which China has become an important hub, and the evolution of China's institutional framework facilitating an attractive location for innovation activities. The article continues as follows: Section 2 introduces the conceptual framework of (co-)evolution. In Section 3, the push-factors as the institutional ownership advantages of the MNCs coming from the small open economy of Denmark are presented followed by a short introduction to the pull-factors of the institutional locational advantages of China in Section 4. Section 5 takes an in-depth perspective of the evolution of four Danish MNCs in China and the trajectories found in their entry strategies over the past three decades. The discussion (Section 6) looks into the interrelationship between the evolution of the institutional framework of China and the Danish MNCs' activities in China. Finally, in Section 7, conclusions and take-aways for MNCs and policies are presented.

\section{Conceptualising the (co-)evolutionary dynamics of internationalisation}

Although current research is striving to develop models of $\mathrm{MNC}$ internationalisation strategies, it is also increasingly clear that MNCs engage in a number of different strategies that are changing over time owing to a variety of dynamic factors. These factors are anchored both internally in the firm and externally in national and international institutions that together form the framework conditions. The different institutional levels of home and host economies and international agreements together constitute a complexity of institutional frameworks within which MNCs operate. The internal and external dynamics of internationalisation were first brought together within international business studies in the work by Dunning (1988), in his eclectic paradigm. This paradigm takes both ownership advantages (O-advantages) and locational advantages (L-advantages) into account to understand how, where and why MNCs internationalise (Dunning, 1992, 2000). Since then, scholars of international business have focused on further developing and fine-tuning the inclusive framework, so that it integrates and combines dynamics at both the firm level and the institutional level of the host location (Dunning, 1988; Buckley and Ghauri, 2004). However, combining the internal dynamics relating to ownership advantages with the external dynamics that relate to the host-location advantages of an MNC remains a challenge, not least with the new emerging market locations gaining importance in the MNC landscape (Dunning and Lundan, 2008).

Still, bringing in host-country institutional settings as framework conditions for international business remains highly relevant, particularly when internationalisation occurs in locations where the MNC experiences a high liability of foreignness (Park, 2016; Forsgren, 2013; Johanson and Vahlne, 1977, 2009). This is the case for many European MNCs entering emerging markets such as China. Meanwhile, both O-advantages and L-advantages are dynamic factors and the evolution of both is often interdependent. For example, as the institutional setting in a location changes, the location may attract more (or less) MNC activity through FDI, and as MNCs gain experience in the location, these companies potentially influence the institutional framework and may also increase the responsibility and role of the subsidiary (Haakonsson et al., 2013). This eventually changes the MNC as an organisational form itself (Cantwell et al., 2010; Cantwell and Mudambi, 2005; Whitley, 2009). 
Understanding these dynamics requires a dynamic and evolutionary perspective to internationalisation at the firm level (Cantwell et al., 2010). Previous analyses have looked at MNCs' offshoring strategies into accessing new markets or slicing up the value chain (Lewin et al., 2009; Mudambi, 2007), and changing dynamics at the intersection between institutions and industry (see Haakonsson et al., 2013; Westney, 2009; Lewin et al., 1999, 2009). However, it remains relevant also to understand the implications and challenges at the firm level, regarding MNCs' strategies for entry into emerging markets. This article brings in the firm level by building on a multiple case-study design of MNCs' entry into China. Integrating an ' $\mathrm{O}$ ' analysis of Danish MNCs with an ' $\mathrm{L}$ ' analysis of the attractiveness of China as a location allows for investigating the trajectories of $\mathrm{MNC}$ subsidiaries into actors that potentially contribute directly to core activities such as MNC innovation processes (Cantwell and Zhang, 2009). This is a relatively new level of internationalisation also called the new geography of innovation (Haakonsson and Ujjual, 2015).

\subsection{Firm-level dynamics}

The internal dynamics that relate to the O-advantages are linked to the process in which MNCs increasingly engage internationally through globalisation of production, market and innovation activities, and develop into global lead-firms or turnkey suppliers in global value chains and production networks (Gereffi et al., 2005; Coe et al., 2008). These exploitation strategies for internationalisation, i.e., market seeking or efficiency seeking, are well established in the literature (Jensen and Petersen, 2011; Kuemmerle, 1999). The strategies intensify over time - or change. As the firms gain internationalisation experience, mature, and over time connect to relevant actors in their host locations, MNCs tend also to embark on exploration strategies, e.g., innovation, and hence MNCs over time develop into global organisations (Kuemmerle, 1999; Archibugi and Michie, 1995). Recent outcomes of this process are the emerging global innovation networks and the new geography of innovation. As MNCs change their engagement from exploitation to exploration strategies they eventually also involve the global generation of innovation and knowledge (Haakonsson and Ujjual, 2015).

Internationalisation strategies that evolve over time have previously been explained by firm level dynamics through path dependent stages, e.g., in the product life cycle (Vernon, 1966); firm commitment to a location (Johanson and Vahlne, 1977); sequential expansion of firm activities (Kogut, 1983); and organisational learning (Kogut and Zander, 1993). Other studies have shown that MNCs are not always as engaged in globalisation as expected and that many MNCs keep the majority of activities within their home region (Rugman and Verbeke, 2005; Thompson and Kaspersen, 2012). However, the size of an MNC's home country matters, as MNCs from small open economies such as Denmark are thought to engage internationally owing to the small size of their home market. Small open economies are generally more internationalised than larger economies (Katzenstein, 1985). This results in some important firm-level features for MNCs from small open economies, as their integration into new locations is linked to their high capability to discover and integrate new combinations of knowledge from and across different sources. Furthermore, specialised and knowledge-intensive firms are likely to internationalise more than others, as their products are potentially 'born global' and innovation expenses are high (Madsen and Servais, 1997). Hence, the push-factors 
experienced by MNCs relate to home market size, specialisation, production costs and capabilities. Generally, push-factors increase as the MNCs gain international experience.

MNCs' emerging market strategies differ from strategies in well-established markets (London and Hart, 2004), and new types of network and different capabilities are needed. MNCs establish relationships with non-traditional partners and develop customised solutions for these markets, sometimes contributing to building local capacity. When MNCs internationalise knowledge activities into emerging markets, changes are required in organisational capabilities (Hoskisson et al., 2000; Malik and Kotabe, 2009; Pronina et al., 2016). Few studies focus on this evolution of MNC strategies (Hobday and Rush, 2007; Iammarino et al., 2008). MNCs are challenged in the role of coordinating and orchestrating different types of network. MNCs increasingly become institutions for connecting knowledge sources. Moreover, theories and research methodologies should be developed to enable new insights into the current dynamics of globalisation (Cano-Kollmann et al., 2016; Cantwell and Zhang, 2011; Meyer, 2004). Although much research looks into MNCs' international engagement, few studies link the push-factors and pull-factors experienced by the companies, i.e., the interplay of locational dynamics in the host country (with some exceptions from the economic geography literature (see Mudambi, 2008; Buckley and Ghauri, 2004; Haakonsson et al., 2013). Taking on a (co-)evolutionary perspective of MNCs' internationalisation allows for integrating the push-factors with the pull-factors (Herstad et al., 2014).

\subsection{Locational dynamics}

The attractiveness of a given location, L-advantages, varies according to the firm strategy for internationalisation, O-advantages, and the type of activities internationalised. However, specific and general framework conditions are necessary for a location to be attractive to FDI into production, market and innovation activities, respectively. The world is not flat, and certain locations are indeed more attractive to MNC offshoring than others (Florida, 2002, 2005). The attractiveness of a location changes over time and is influenced by factors within the institutional framework and global industrial dynamics (Haakonsson et al., 2013). Geographically, MNC internationalisation was initially confined to advanced economies in Europe, Japan and the USA (Cantwell, 1995; Patel and Pavitt, 1992; Verspagen and Schoenmakers, 2004). However, over the past three decades, emerging markets have gained attractiveness for offshoring. China in particular has evolved into an attractive location for R\&D activities owing to a combination of low production costs; economic growth; government requirements of local content; and increased availability of innovation and knowledge capabilities (Ernst, 2006; Liu et al., 2013; Santos-Paulino et al., 2014).

Focusing on how institutions affect the attractiveness of an emerging market location further emphasises the need for taking an evolutionary approach, as is implicit in the term 'emerging market'. Hence, focus must be on how the evolution of the institutional framework shapes the business environment. Looking into the interrelationship between ownership and location advantages, Dunning and Lundan (2009) established how different drivers of FDI in MNCs led to different types of engagement in economies, noting that certain L-advantages attract MNC activities of different degrees of embeddedness into a host economy, e.g., exploiting strategies led to less embeddedness to FDI than exploration strategies. Others link MNC internationalisation to host-country 
institutional and legal frameworks (Peng et al., 2008; Hoskisson et al., 2000) and country-specific technological advantages (Feinberg and Majumdar, 2001; Shan and Song, 1997; Kogut, 1990) such as the national systems of innovation (Freeman, 1995).

Hence, as different MNC activities are likely to become offshored into an emerging market location along with the evolution of that location, it is relevant to look into the evolution of the institutional framework to this development. Institutional frameworks such as the policies for FDI and industry in general, the openness and size of the economy and the risks of investing in a given location form the pull-factors of the location. The attractiveness varies: for efficiency seeking, cost of production is most important; for market-seeking investments, market growth; and for asset seeking, the knowledge and capabilities available are paramount. Emerging markets are also emerging locations of innovation activities relative to the absorptive capacity, technological capabilities and market specificities (Teece et al., 1997). From a country perspective, emerging market locations evolve from catch-up processes to high-level technology development, and need more linkages with the outside world in order to obtain knowledge and technology for industrial development. MNCs are critical actors in this process (Cantwell and Piscitello, 2014).

\subsection{Inter-dynamics between the firm level and locational dynamics}

Having established that as the characteristics of a location changes, its attractiveness for MNC investments also change, it is clear that the same goes for MNCs: as they gain experience in a specific location or in emerging markets in general, their engagement and types of activity also change in the locations. This interrelationship between investing firm and locational dynamics again evolves over time as the location changes with the needs of the MNC. Where low-cost production factors may have been the more attractive pull-factor in the first place, the growth of the market and MNC experience in the location may open up for relocating market activities and eventually innovation activities. Hence, looking at the evolution of MNC investments, there is a clear tendency for consolidation and expansion within a given location. Whether investments into emerging market locations follow the trajectories remains unclear.

Archibugi and Michie (1995) developed a taxonomy of internationalisation based on the dynamics experienced by firms as they relate to innovation. This taxonomy argues that MNCs' involvement in a location follows three main stages (see also Archibugi and Iammarino, 1999). Firstly, MNCs engage through market-seeking or efficiency-seeking strategies - what they call international exploitation. This involves market entry, marketing and production. Products involved are invented in the home country and introduced to a new location through exports, licensing and offshore production. Secondly, as the MNCs get engaged in a location, they realise that the host economy faces different market demands and has different capabilities from the home economy. The MNCs then move towards adaptation of products to the local market and engaging with relevant actors in the host economy through global generation of innovation. This involves reorganisation, global restructuring and relocation of new activities. Thirdly, as the MNC engages with new actors in the host economy, it becomes clear that these potentially complement the MNCs' home-based capabilities. The MNCs also tend to engage in joint innovation projects (Haakonsson and Ujjual, 2015).

Over time, activities carried out in foreign subsidiaries potentially contribute to MNCs' global competitiveness (D'Agostino and Santangelo, 2012; Zanfei, 2000). In 
other words, the (co-)evolutionary dynamics play a central role in linking MNC internationalisation and the evolution of the institutional framework impacting the location's attractiveness for MNCs and for their embeddedness into a host country. MNCs' embeddedness and engagement in innovative activities are cumulative, path-dependent processes (Dosi, 1982); hence, it is relevant to look into the trajectories of internationalisation. Moreover, the sequence leading to MNCs' internationalisation of innovation thus becomes a trajectory that relates to the evolution of a given institutional framework.

The proposed framework of (co-)evolutionary processes distinguishes between the push-factors relating to the O-advantages of the firm, its home economy and the types of product that drive MNCs to internationalise certain activities. These relate to the need for market access, cost-efficiency or accessing capabilities not available in the home country. Furthermore, it relates to the pull-factors, the L-advantages, constituted by market size, and the availability of relevant human resources and technological know-how. Hence, internationalisation of an MNC into a given host location depends upon locational characteristics and the firm and its experiences (Lewin et al., 1999; Coe et al., 2008). This article investigates this as a trajectory, a sequence of incidences for similar firms experiencing a similar history. As Koza and Lewin (1998) put it, an evolutionary perspective draws on a multiple framework 'beginning with the antecedent and founding conditions, negotiating and establishing expectations for creating and distributing joint value, the (co-)evolution for direction, structure, and practices in concert with the evolution of the constituent firms, industry and society' [Koza and Lewin, (1998), p.256].

A general pattern of globalisation of knowledge-intensive industries can be understood as a dynamic process following these four steps:

1 low-cost-seeking strategies (outsourcing, offshoring of production)

2 market seeking strategies (localisation of products)

3 collaboration with host-country actors (adaptation and increased competencies of local producers)

4 globalisation of innovation (subsidiaries get a global mandate) (Volberda and Lewin, 2003).

Summing up, in order to understand the interrelationships between location and MNC strategy, an analytical model is developed encompassing host-country dynamics (pull-factors) and country of origin (push-factors). This allows for understanding the patterns of internationalisation of MNCs from small open economies into emerging markets. Methodologically, the article is based on in-depth case studies of four large Danish MNCs' entry and evolution into the Chinese location. The selection of these four MNCs was based on certain criteria. First, in order to investigate trajectories, the time and experience in the Chinese market should be at least a couple of decades. Second, the type of activities offshored to China by the MNCs needed to have reached a stage where also innovation activities were offshored. Finally, for comparative reasons the MNCs should have a strong historical embeddedness in the Danish home economy. The names of the companies are not mentioned owing to confidentiality reasons. The case studies have been conducted over time in order to understand the dynamic drivers of these firms in the Chinese context. Hence, 21 qualitative interviews have been carried out with strategic managers from headquarters and managers at different levels from their Chinese 
subsidiaries in the period between 2008 and 2016. Findings from interviews at different levels and across Denmark and China were triangulated in order to enhance reliability of the findings. On the development of the Chinese location's attractiveness for offshoring MNC activities, an in-depth desk study has been carried out looking into the regulative changes in Chinese politics as they relate to foreign firms. The focus has been on the general regulations as well as on the regulations that particularly affect Danish firms, such as the Renewable Energy Law from 2005. Along with the desk study 15 interviews have been carried out with experts involved with Chinese FDI policy. Again owing to confidentiality issues, company names will not be disclosed in the article. However, for the reliability of the findings all four case studies are 'extreme' in the sense that they represent some of the largest and most internationalised Danish firms.

\section{Push-factors: Internationalisation from a small open economy perspective}

The internationalisation of Danish MNCs is based on features in the home economy that are unique to the Danish industrial sector. Owing to the fact that Denmark is a small open economy, globalisation of Danish firms has a long history and the economy has gone through a number of processes, some of which still prevail. Generally, the economy has experienced a high level of international trade, with extensive outsourcing and offshoring of production increasingly to low-cost areas. Recently, the MNCs have also increased international collaboration in innovation activities. Consequently, some of the largest Danish firms have been early movers in establishing global production and innovation networks at the global scale (Haakonsson, 2012).

Danish MNCs are generally characterised by a high degree of internationalisation and export-oriented production structures. It is worth noting that among the large-scale companies, the export ratio is more than $50 \%$, which has created a new league of large globalised corporations (Iversen et al., 2008). In fact, Denmark's strong export-oriented economy relates to the small size of its home market (Katzenstein, 1985). According to Katzenstein (1985), small economies depend on internationalisation to achieve continuous growth and sustain their competitiveness. Consequently, it is likely that small economies are more globalised than larger ones. According to a study by Benito et al. (2002), which compared the ten largest companies in Denmark, Norway and Sweden, large Danish companies were more globalised and their share of international activities had grown considerably since the beginning of the 1990s. Another study of large corporations by Meyer (2006) showed that large Danish companies globalised by developing into global specialists within different niches.

A comparative report from 2008 by the statistical agencies of the Nordic countries showed that $52 \%$ of Danish companies with more than 50 employees practised international sourcing. The report also showed that $13 \%$ of the companies engaged in international sourcing offered 'access to specialised knowledge/technologies' as their motivation for outsourcing [Statistics Denmark, (2008), p.54]. This is a small segment of Danish businesses; nonetheless, it shows that Danish MNCs are relatively more engaged in international networks, based on strategies to access complementary knowledge. 
Figure 1 FDI from Denmark to China 1982-2015 (million USD), (a) FDI flow (b) FDI stock

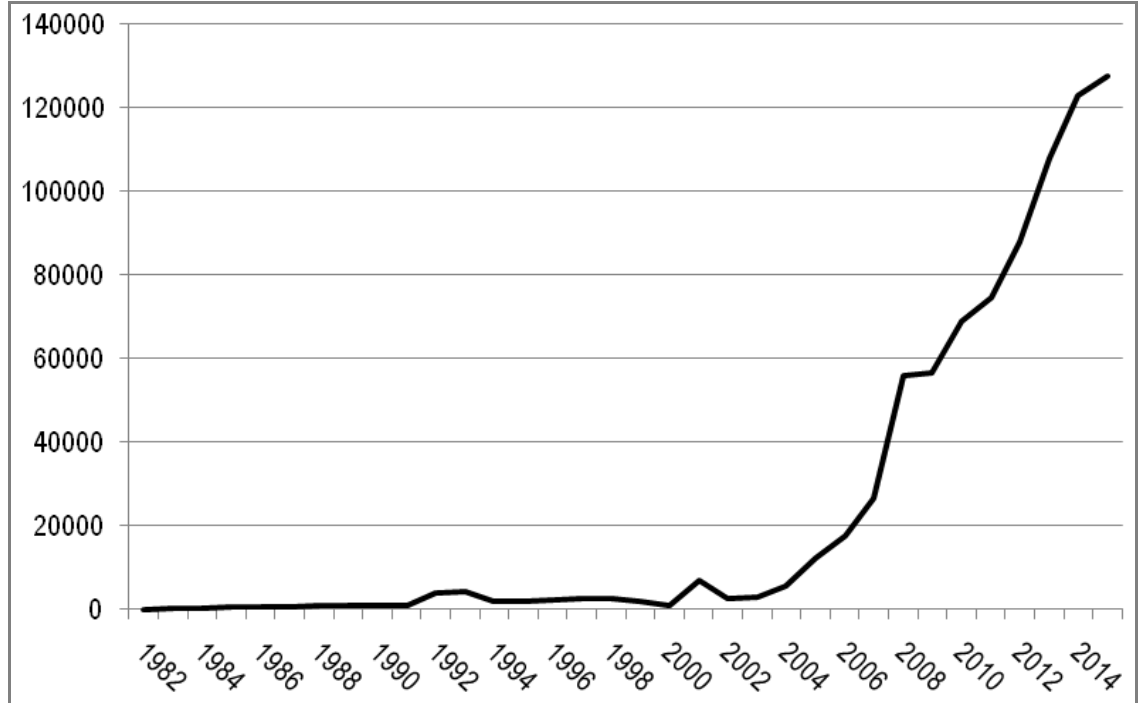

(a)

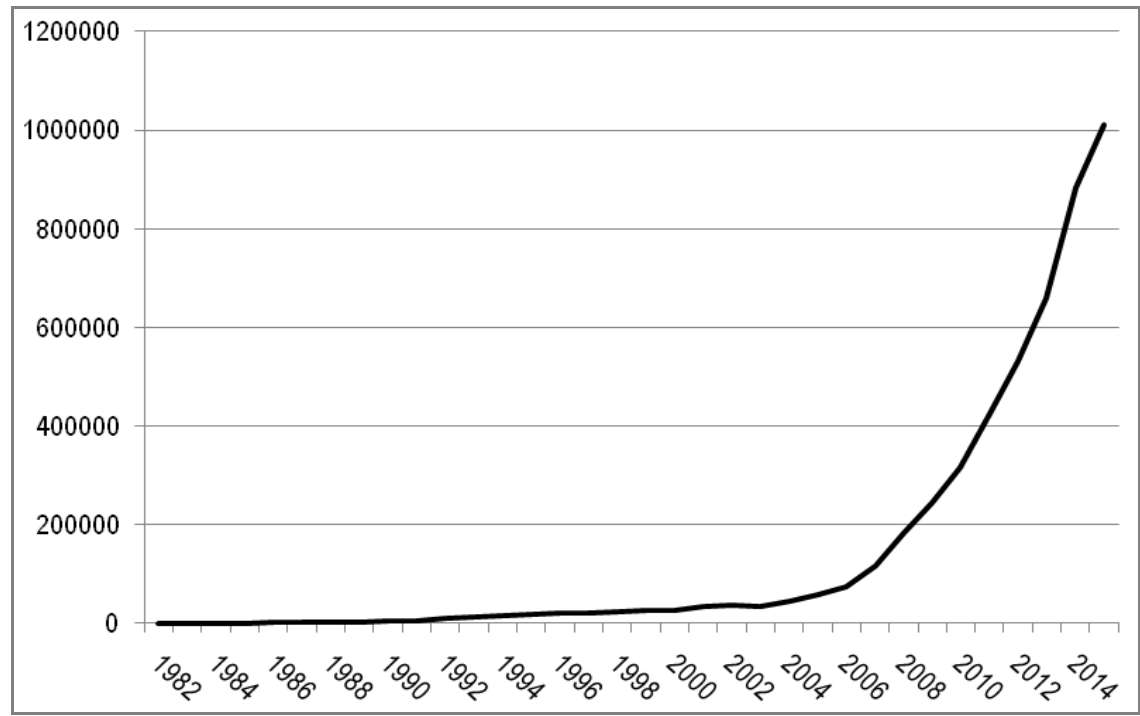

(b)

Source: Statistics Denmark, http://www.statistikbanken.dk (accessed October 2016)

Still, Danish companies are generally not globalised beyond Europe. They predominantly orient their internationalisation strategies towards Europe. In 2008, Danish companies had a total of 8,423 foreign subsidiaries. The majority of these $(76 \%)$ were located within Europe, followed by Asia (10\%), North America (6\%) and the rest of the world (8\%). In 
terms of employment, the distribution was a bit different: $28 \%$ of employees in subsidiaries of Danish firms abroad were in Asia, 56\% in Europe, $8 \%$ in North America and in the rest of the world $11 \%$. When calculated together, Danish companies source more from outside than from inside the national economy. Only $2.7 \%$ of all the companies were involved in international R\&D sourcing; however, this was the most widely globally distributed activity of companies' sourcing activities. In particular, China stands out as an important location for R\&D outsourcing. The Danish accumulated stock of FDI into China as well as the annual flows of new investments are illustrated in Figure 1.

Hence, coming from a small open economy, Danish MNCs face push-factors for internationalisation and Asia is an important location in this process. However, within Asia, China is the location that attracts most Danish investment, not only in production facilities but also in R\&D. One main factor is the size of the country, but the investments and engagement rely on the policy framework for foreign investment, too. This will be dealt with in the following section.

\section{Pull-factors: the evolution of China as an attractive location for FDI}

With the transition from a socialist planned economy towards a gradually more market-oriented economy, the location attractiveness for FDI has undergone immense changes in China. From a closed economy up until the end of the 1970s, the country had become the largest recipient of FDI among developing countries by 1993 . However, the attention of foreign MNCs continued to surge in such a way that from 2005 onwards China was in the global top three FDI recipients (Long, 2005; Puck et al., 2009; Oxelheim and Ghauri, 2008). When looking at the institutional framework, the evolution of China as an attractive location for FDI roughly divides into three stages: The first stage started with the Open Door Policy in the late 1970s and continued throughout the 1980s. During this stage, the Chinese Government focused its industrial policies on building up an export-oriented production base that could compete internationally. For foreign MNCs, however, it implied a high level of restrictions regarding entry mode and restricted access to the domestic market. The policies of the second stage allowed for more flexibility and encouraged technology transfer to facilitate upgrading and capacity building in the local production base. This period ran throughout the 1990s up to the World Trade Organization (WTO) accession in 2001. The third and current stage overlapped with the market liberalisation required by the WTO and aims at promoting $\mathrm{R} \& \mathrm{D}$, innovation and lifting the domestic industries into the tertiary sector while gradually integrating Chinese firms into the global market economy.

In the early years of the first stage aimed at establishing an export-oriented production base, FDI was confined to joint ventures with Chinese companies within special economic zones placed in strategic locations along the east coast. Foreign companies were obliged to follow the central government's development objectives through criteria aimed at export proportions, local content requirements, foreign exchange balance, technology transfer and the like (Long, 2005; Liu, 2015). Some of the ownership obligations were relaxed step by step from requiring joint venture partnerships to allowing wholly foreign-owned enterprises and even encouraging them at a later point in time (Shenkar, 1990). Market access, however, remained restricted throughout this first stage, which meant that foreign companies primarily were pursuing efficiency 
enhancement by tapping into cheap resources for export. Imported goods were subject to high tariff barriers, but through the Chinese Trade Processing Policy intermediary raw materials and spare parts were exempt if the final product was headed for export (Shenkar, 1990; Long, 2005; Li, 2013). The influx of FDI and the incremental build-up of a modern production base allowed China to expand its infrastructure, improve the quality of its labour force and develop its state-owned enterprises, which played a major role in the domestic economy. At this stage, there was very limited focus on R\&D, which would change over the course of the second stage (Gassmann and Han, 2004; Li, 2013).

The second stage focusing on industrial upgrading and market access was realised as a consequence of slow FDI growth in the early 1990s. MNCs remained cautious after the Tiananmen incident. In 1992, after Deng Xiaoping's Southern Tour, the political and economic conditions for foreign MNCs were improved, which triggered a new wave of FDI inflow (Shenkar, 1990; Liu, 2015). The Chinese Government deregulated the ownership control limitations for foreign investments, encouraging technology transfer and the establishment of MNC R\&D centres. This allowed MNCs greater flexibility and a better framework to protect their technology, and led to a surge in the registration of wholly foreign-owned enterprises in the country (Liu, 2015; Li, 2013; Gassmann and Han, 2004). Political risk for foreign investment was reduced and the domestic infrastructure improved along with the economic development. Furthermore, the Chinese market was opening up and the institutional procedures were streamlined compared to the previous stage. The aim behind the Chinese FDI policies had changed away from an export-oriented focus towards a strategy-supporting market entry, local adaptation and upgrading by getting MNCs to fill in technological gaps in the Chinese industrial sector by introducing advanced technology and improving existing technology. In 1997, the government also revised the Catalogue for the Guidance of Foreign Investment Industries for the first time. This catalogue spells out both preferential treatment and restrictions on FDI depending on the sector. By the end of the decade, a new preferential tax regime was put in place to promote localisation of MNCs' R\&D (Long, 2005; Li, 2013; Gassmann and Han, 2004). At this point, MNCs still experienced a strong divide between the Chinese and the international market, thus R\&D was mainly in adapting existing products to the Chinese market as opposed to establishing global centres of excellence (Long, 2005).

With China's accession to the WTO, the country embarked on the third stage focusing on technology transfer and indigenous innovation. This implied a policy shift towards promoting indigenous innovation and increased technology transfer through R\&D activities in China. With the accession to WTO China abandoned the majority of the barriers to investment as were set in the Guidelines of Foreign Investment Industries, and has since gradually been revising it to provide a more level playing field between foreign and domestic players. However, these revisions have also shown a move towards focusing more on indigenous innovation and further away from export-oriented manufacturing (Long, 2005; Blanchard, 2008; Wei et al., 2012). At this stage, the government is encouraging foreign MNCs to further engage themselves with the Chinese industrial environment (Wei et al., 2012) thus facilitating domestic industries moving up the value-added chain (Blanchard, 2008). The third stage involves promotion of high-tech industries (Stratfor, 2010) and aims at attracting innovation activities instead of labour-intensive activities. Several new industries have emerged during this stage. One example is the wind turbine industry that developed owing to the introduction of the 
Chinese Renewable Energy Law in 2005. This law aims at increasing access to boost renewable energy by, among other issues, technology transfer.

Today, 1200 foreign MNCs have their R\&D centres in China and the number is still increasing. Mainly these are also the largest MNCs, and the R\&D centres are located in the major cities, which they see as the centres of talent (interview industry specialist, Beijing, 2015). Besides the preferential policies towards MNCs with R\&D investments, the MNCs also gain access to the large number of Chinese experts coming back from overseas and the exceptional increase in Chinese investments into R\&D. More than 18,000 scientists have returned and, currently, there is $33 \%$ annual growth in $R \& D$ investments in China. This level of capacity building has so far not been seen in Europe. The Chinese Government's ambition for China to become an innovative country by 2020 has increased the level of R\&D-related FDI into the country.

Over the course of 30 years, China has gone from being a restricted economy to becoming one of the most popular destinations for FDI in the world (Long, 2005; Liu, 2015). The FDI composite has largely changed over the three stages: when the Chinese central government provided favourable policies for export-oriented production, it shaped the industry conditions and thereby the investment influx; the turn towards opening the domestic market and value-added upgrading of the domestic industry further boosted FDI flows into the country; then, more recently, with the focus on the development of a tertiary sector and indigenous innovation, the share of manufacturing activities in the aggregated level of FDI is on a decline compared to that of the service sector (Li, 2013).

Figure 2 Inward FDI flow to China 1979-2015 (million USD)

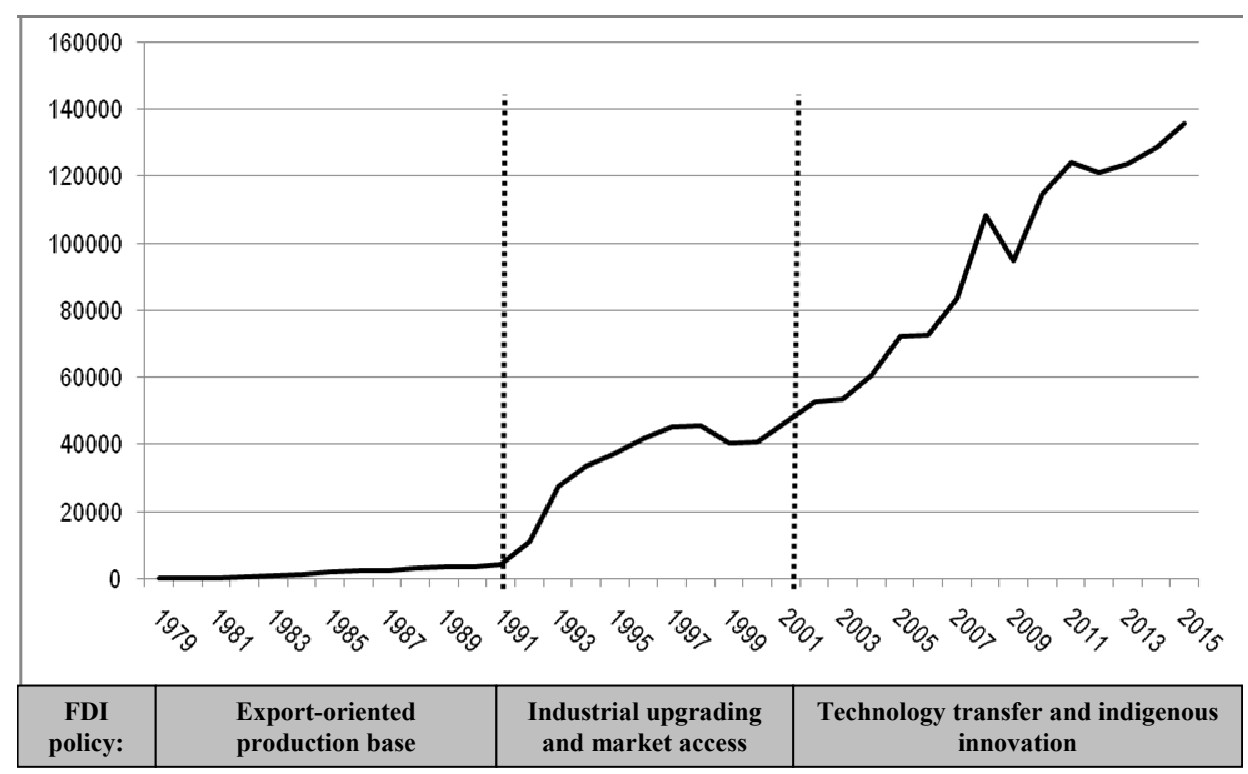

Source: UNCTAD

Figure 2 shows the development of inward FDI to China during the three stages. Around the time of the accession to the WTO, FDI increased again after a slowdown in the late 1990s. According to Walmsley et al. (2006), the accession significantly boosted investment and doubled foreign ownership of Chinese assets owing to the improved 
market incentives for foreign investors (Shenkar, 1990; Gassmann and Han, 2004). Lately, inward FDI has further increased immensely as MNCs are attracted to the market of skilled labour and innovation ( $\mathrm{Li}, 2013)$.

\section{A fairy tale of four Danish companies' entry into China}

Danish companies have been increasingly attracted to the Chinese location over the past decade. The opening of the Chinese economy along with the availability of labour and production capacity has been the main attractions throughout the 1990s. However, recently the firms are increasingly engaging with domestic Chinese actors for partnerships, for several reasons. Access to market and understanding the market through overcoming their liability of foreignness are the main drivers of the establishment of these partnerships. However, they tend to develop over time. The companies are all among the largest Danish firms and are specialised in two of the strongest Danish industrial sectors: two in engineering (PumpsDK and WindDK) and two in pharmaceuticals and biotechnology (PharmaDK and BiotechDK). Three of the companies are engaged in the production of sustainability solutions (WindDK, BiotechDK and PumpsDK). All four are now at a stage of engagement that involves R\&D and innovation at different levels. In the following, the four Danish MNCs' entry into China will be presented in order to establish whether a trajectory of the Danish MNCs in China can be identified.

\subsection{Danish MNCs in China}

PumpsDK has undertaken a number of reorganisations owing to globalisation, in particular since 1980 when the firm started reorganising activities beyond market seeking into new locations. Among these new locations, China has developed into what the company calls its 'second home market' (interview, 2010). In the last decade, PumpsDK has also reorganised innovation and, according to the current global strategy, is pulling towards a global organisation with core innovation responsibilities dispersed into its global sites. This direction has become particularly explicit in the new global set up of $R \& D$ in which each subsidiary with $R \& D$ activities is allocated to be a lead unit for developing and maintaining a particular range of specific technologies. This set up is coordinated by the headquarters in Denmark, which is also the primary unit for running new production lines. As the production lines mature, a series of production allocations takes place concurrently with the global expansion of operations and market presence.

PumpsDK has been operating in China since 1994 and today has a full-scale operation including sales, after-sales service, production, R\&D and technology development activities. Before China's open door policies, the company had a sales office in Hong Kong to access the Asian market with imported products developed and produced in Denmark for the Chinese market. In 1994, the first production site was set up in China. The purpose was to reduce production costs and there was no development involved. According to a Chinese manager, the Danish headquarters and in particular the R\&D unit had a 'leave me alone' attitude (interview, 2013), not taking into account ideas and developments from the Chinese subsidiary beyond mere problem solving. In 2006, the company also began to approach the Chinese market with products produced in the 
Chinese subsidiary. The China-based R\&D and technology centre started its operations in 2007 with the objectives of supporting the second home market strategy and gaining access to resources and employees in China. An engineering unit was set up to cater for product development for the Chinese market and the number of R\&D staff increased from two in 2006 to 112 in 2012. As the R\&D grew and matured in China, the company realised the potential for integrating the Chinese technology centre into its global operations. In 2012, this site became a 'centre of excellence' for certain product types. A few years later, the first product developed in and from China reached the market: "The process itself involved researchers from the US, Holland and Finland, but it originated in China. So, now we have for the first time a global product that is owned in China. The Danes also like it" (interview, 2013).

Today, the Chinese subsidiary has 1,600 employees and operates with dual headquarters in Beijing and Shanghai, two distribution centres, four factories, 60 service centres and 140 licensed dealers in China. The products are adapted to the current challenges facing China, especially sustainability, in particular within four market segments: building services, industrial pumps, water supply and district heating. The Chinese technology centre has gained a global mandate and collaborates closely with the global organisation within its technology fields. According to the managing director, this centre has a critical mass and is very capable in product development also due to the available human capabilities: "The world's best hydraulic engineers actually come out of an university in China and the design of at least two of our big products is entirely done in China" (interview, 2014). With this development and global integration, the company has also prioritised the development of a company culture to facilitate global integration and interdisciplinary projects across teams, e.g., recently a product was developed in collaboration between China, India and Denmark.

PharmaDK is a world leader in a very specialised product range. Hence, specialised human resources are core to the company. It operates globally with global products that are practically applicable to all markets. One of the main strategies is to tap into the right minds - the right people for developing new blockbusters. Owing to the slicing capability and codifiability of innovation and production activities in pharmaceuticals, production and product development are today globalised into specialised units. Activities are dispersed across different global units specialised in different stages of development and production of new drugs.

In 1980, the company set up a sales only office in Hong Kong for the Chinese market, based on an exploitation strategy for market entry. In 1994, PharmaDK opened its first production site in China. As a cost-reduction strategy, and based on the lack of local capabilities for production, this site dealt with packaging of products produced in Europe mainly for the global market. After the turn of the millennium, the company started focusing on how to gain more access to the Chinese market and set up an R\&D unit in Beijing. According to one of the managers, this was initiated through a wish to improve its standing with the Chinese Government in order to gain market access by creating an image as a trustworthy business partner in China, as was confirmed by a manager explaining the early R\&D investments: "Frankly this was about market" (interview, 2012). As this unit grew and became more capable, it also developed into a site to support R\&D processes developed from Denmark. In 2009, the Chinese site was the core location for activities in the early stages of the value chain, i.e., screening of molecules and proteins. The screening activities are highly codifiable and isolated tasks. "When we are assigned a task, we know exactly what they want" (interview, 2014). 
Along with the offshoring of R\&D activities, the company also established collaboration with Chinese universities for recruitment and sourcing, which over time became essential for the global operations. The R\&D manager in China explained this as being "very much about attracting the right people [...]. Not many Chinese people want to go to Denmark [...]. The best Chinese are of course fully at the level with the best Danes, and in absolute numbers there are a lot more of the really good candidates than in DK - but not necessarily cheaper!" PharmaDK has benefitted a lot from getting access to returnees from the US who are highly specialised within the pharmaceutical area of the company. Since 2013, 10\% of the company's global R\&D takes place in Beijing and the plan is to develop this into a centre of excellence. The Chinese subsidiary has experienced rapid growth, e.g., in research staff it has grown from less than 50 in 2006 to more than 250 in 2015. All the research activities carried out in China is for the global market: "we have no innovation here for the local market, our target is the global market. Although we have a production site and a marketing office nearby, we do not collaborate. All goes through Denmark" (interview, 2014). The Chinese market is also growing by almost $50 \%$ each year.

BiotechDK is a large-scale developer and producer of bio-based solutions for a large range of industries, e.g., food, energy, agriculture. All products are applicable to the world market and the MNC is highly globalised in its operations. Much of the product development is based on customer engagement, as the products go into other companies' product development through business-to-business relationships. Therefore, it is important for the company to (co-)locate some innovation activities in proximity to its customers. Products developed for one customer in one industry are often applicable to other customers in other industries. Innovation, diversity and communication are central to the company. The current strategy of 'innovation creation through diversity' (interview, Vice President, 2014) has taken the company on a 'journey of internationalisation of production, markets and R\&D into emerging markets'. China is the main emerging market location of BiotechDK.

BiotechDK opened its first sales office in Asia in 1972, in Hong Kong. In 1982, the first office was established in mainland China, in Beijing. Both these offices were sales offices following the exploitation strategy of accessing the growing Chinese market for bio-based solutions. In 1995, two production facilities were set up in China: one was a joint venture producing for the Chinese market and the other a fully owned subsidiary set up in a special economic zone for exports. The joint venture was during the following decade taken over fully by BiotechDK. The company inaugurated its first Chinese R\&D competence centre in Beijing in December 1997 with the tasks of developing and adjusting products for the Chinese market and engaging with Chinese customers. In 2005, the company introduced the first developed-in-China product in the global product portfolio. Having a high degree of specialisation in an industry with few local competitors, the company quickly grew and gained an almost 50\% market share. In 2007, the company had a huge expansion and entered into two very successful partnerships with large Chinese state-owned enterprises in food and energy.

Since 2008, the China subsidiary has been a centre of excellence in the global operations of BiotechDK. The Beijing technology centre is today specialised into two core R\&D responsibility areas, for which global technology leadership is located in China. The subsidiary was further expanded in 2009 with the inauguration of the MNC's largest global production facility, in China. Again, in 2011, a new plant was opened in 
China with an investment of more than DKK 300 million. At that time, the Chinese BiotechDK subsidiary R\&D centre had developed into an organisation of roughly 100 full-time employees focusing on basic research, global projects and various applications for the Chinese market. Two key technology areas are still being controlled from Beijing.

WindDK is a producer of renewable energy solutions for the global market. The company is an engineering company focusing on development, production and implementation of wind energy. It is well anchored in the Danish national innovation system for wind turbines. Along with the international political attention towards renewable energy solutions, WindDK has undertaken an expansion and exploitation strategy through FDI in all world regions. China is one of the largest markets for renewable energy and therefore China has also been an attractive location for the company since the mid-1980s. As climate, energy systems and integration, electricity grids, wind conditions, etc. are different in different locations, research and innovation have also become globally distributed. In 2012, the company completely reorganised its R\&D from being Danish into a system of globally distributed research and innovation facilities: 'We believe we can do decentralised innovation' (interview, Manager, Global Innovation). Furthermore, the company needs to understand local requirements, for example in China, where wind turbines are not necessarily integrated systems as in Europe, but are based on a more modular architecture that generally fits emerging markets better (Haakonsson and Kirkegaard, 2016).

WindDK had an early entry into the Chinese market as it built the first wind turbine there in 1985 in close collaboration with the Danish embassy in Beijing and its projects on renewable energy exports to China. In 1995, the first sales office opened in Beijing. For a decade, turbines were imported from Europe as this industry did not face local production requirements until 2005. In 2006, after the implementation of local content requirements of $70 \%$ by the Chinese Government along with the Renewable Energy Law, WindDK's involvement in China really took off. As a Chinese manager put it: "What drives the growth is Chinese policy. The passage of the renewable energy law was kind of a kick-off, but 2006 was the real take-off. We couldn't produce enough turbines to sell!" (interview, Manager, China, 2011). Since then the company has established production facilities at Tianjin and Inner Mongolia following the overall principle of "in the region for the region" (interview, 2011). "For logistics purposes, for pricing purposes and for showing our goodwill, we like to manufacture the turbines in the local market" (interview, Denmark, 2011).

In 2010, the company faced political incentives to set up local R\&D facilities: "There is some preferential treatment. So, [WindDK] has since it arrived in China slowly built up and localised certain parts of the supply chain, gradually [...]. We are a vertically integrated company: some components we keep for ourselves. We sell them here. Offshoring of R\&D was a logical step in this development of engagement" (interview, Country Manager, China). Other reasons have also been mentioned in the company interviews: "The reason that we have set up R\&D in Beijing is that it is mandatory to have an R\&D centre and office localised in China if you want to sell turbines" (interview, government relations manager, 2012). Hence, the centre was initially established on the basis of Chinese Government policies for R\&D into innovation: "The thing that I would add in regard to China: There is a phrase called 'indigenous innovation' - you may have heard [of it]. That is a big issue. But just a couple of months ago, the company announced our new global flagship product. This was co-developed with the Beijing R\&D 
centre [...]. I have been working on this and, yes, it is demonstrating something" (interview, China engineer, 2013). In other words, the R\&D centre has changed from predominantly accommodating a wish from the Chinese Government to attract $\mathrm{R} \& \mathrm{D}$, to increasingly being a hub for new innovation and attracting talents to the MNC: "It is no secret that China is graduating most of the world's engineering students and human resources in general" (interview, China manager, 2015).

\subsection{Trajectories for Danish MNCs' entry into China}

The four case MNCs' entry paths into China demonstrate how important China has become to large Danish MNCs. For all four companies, China has developed into the main emerging market location or a second home market. Even before the opening of the market, these MNCs had their strategies oriented towards the Chinese market via sales offices in Hong Kong. From the mid-1990s, three of the companies invested directly in China by setting up production facilities. This was predominantly for export and led by a strategy of cost reduction. With the new millennium, the MNCs changed their strategies to also aim at the Chinese market. This led to investments into development of products in order to adapt these to the local market and increase the embeddedness of the companies in the Chinese context. All four companies established R\&D or technology centres between 2007 and 2010. Between 2008 and 2012 the R\&D centres were each given the status of 'centre of excellence' and with this their mandate in the global organisations increased. As of today, the R\&D centres in China all have a role in the global R\&D set up by the companies, whether specialising in certain products (DKbiotech, DKpumps) or certain innovation segments (DKpharma, DKwind).

Hence, a general pattern - or a certain trajectory - can be identified in the internationalisation of these Danish MNCs into the Chinese location:

1 allocation of production to reduce cost and increase efficiency

2 further involvement and market-seeking investments, e.g., adaptation

3 asset seeking and research for global innovation.

The shift from one strategy to the next connects with the maturity of the firm in China. Whereas BiotechDK was an early mover in all three developments, WindDK invested slightly later - but faster. The MNCs increasingly offshored R\&D to China as they realised the capabilities available there, but all four expressed that experts and researchers are not cheaper in China, sometimes on the contrary. Two of the MNCs are in close collaboration with central Chinese universities and state-owned companies.

The entry and evolution of the four companies into the Chinese economy has followed the same trajectory with a general pattern of a sequence from low-cost-seeking strategies (outsourcing, offshoring of production), to market expansion (localisation of products, adaptation), to innovation and collaboration with local actors in China, tapping into special capabilities and centres of excellence. These shifts in strategy have happened roughly in certain phases, with some variation (see Figure 3). During the evolution of their China engagement, the MNCs have increased the mandate of the subsidiary into being part of all global operations and innovation. 
Figure 3 The evolutionary trajectory of Danish MNCs in China

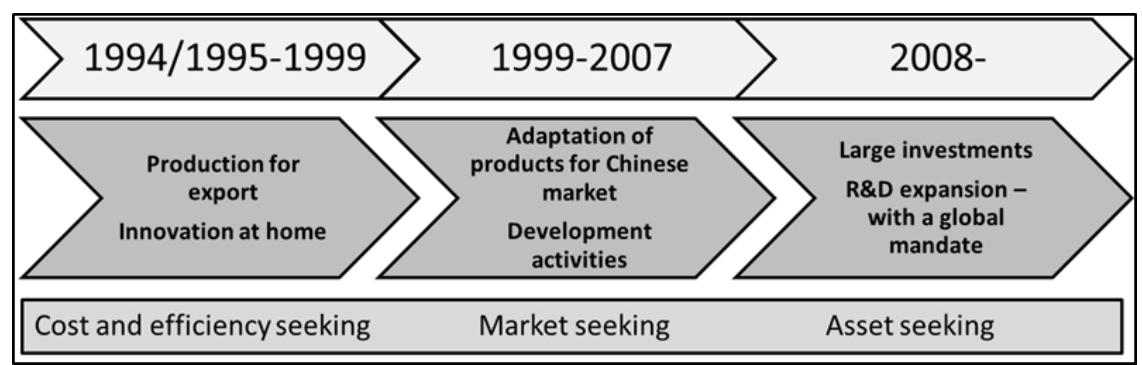

Source: Own data

\section{The (co-)evolutionary dynamics of China as a location for Danish MNCs}

Looking at the interrelationships between the Danish firms' engagement in China and the evolution of the Chinese policies towards FDI, a very interlinked pattern emerged, with the development of the Chinese location advantages (L-advantages) for foreign firms on one side and the strategies and investments carried out by the four Danish MNCs on the other. For each stage of the Chinese economy's opening towards MNCs, i.e., the opening for export-oriented production, the opening of the Chinese market, and the policies for attracting technology transfer and indigenous innovation, the Danish MNCs have increased their engagement in the Chinese location, i.e., from low-cost-seeking production, to market-seeking strategies and relocation of innovation activities into the Chinese context. Figure 4 illustrates this interlinked process.

Figure 4 The evolutionary dynamics between Chinese FDI policies and Danish MNCs

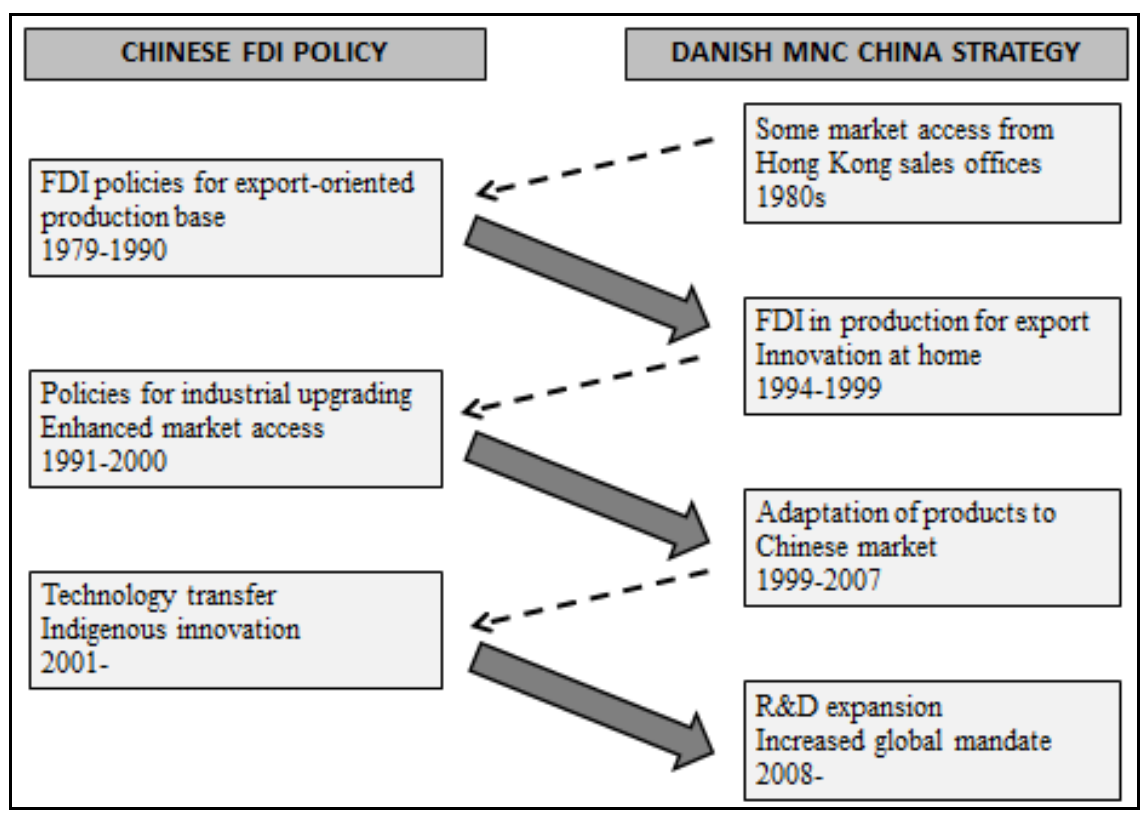


Bringing in the (co-)evolutionary framework helps understanding of these dynamics. However, where the Chinese policies have a strong impact on the MNCs' strategies, the opposite does not seem to be the case. In fact, the changing of MNC strategies appears to be very much a reactive process, reacting to changes in Chinese policy, while Chinese FDI policy is not necessarily linked to MNC development. Furthermore, the Danish MNCs are not taking (or given) an active stand in the evolution of the Chinese policies, meaning that the (co-)evolutionary approaches developed in advanced economy contexts are not directly applicable in an emerging market context. The institutional framework impacts MNC strategies, but the MNCs do not impact the institutional framework, at least not as directly. Rather, from a political level, MNCs are seen by the Chinese Government as tools to achieve certain industrial developments. This is different from what companies in general experience in their home country and in other advanced economies.

Looking at the four MNCs there is a clear trajectory from production to market and further into innovation that follows the evolution of the MNC in the location as well as the policy developments in China. This evolution of the MNCs in China will potentially lead to a change of the MNCs themselves as the Chinese sites have gained strong mandates in their global operations. The changing policy environment along with the availability of talents and markets carry parts of the explanation for the changing MNC strategies. However, as shown in Figure 4, this timeline has a slight delay from when policies were implemented to when the companies adjusted their strategies and engagement in China. This delay varied according to the type of company. The biotechnology company and one of the engineering companies (PumpsDK) were early in adapting their strategies to the changing Chinese environment. The pharmaceutical and wind turbine companies engaged much later on when they were more or less forced to it in order to retain access to the Chinese market for their products. All four firms are now at a stage where their Chinese R\&D units have gained 'centre of excellence' status, catering for the global innovation set up of the MNCs. Hence, China as a location has gained a strong position in these MNCs' distribution of innovation activities - and in general probably in the 'new geography of innovation'.

\section{Conclusions}

This article set out to investigate the trajectories of MNC internationalisation into emerging markets. By looking into the evolution of four MNCs from a small open economy, Denmark, the article found a clear trajectory from offshoring of production, to market, to innovation. The trajectory follows the changing policy framework of the Chinese Government towards FDI. Over three decades, these four MNCs have evolved into a stage where the R\&D centres in the Chinese subsidiaries have become global centres of excellence. The changing mandates of the subsidiaries also change the MNCs as a whole as they reconstruct R\&D into global innovation networks. Only a dynamic perspective can embrace the interrelationships and dynamics at the relevant levels. This supports the argument for applying an evolutionary framework to international business that builds both on the firm level and on the locational factors that together form the push- and pull-factors driving MNCs' internationalisation. 
The key contribution of this article is hence that the process of internationalisation of innovation needs to be seen from a combined framework bridging international business and economic geography. The current construction of a new geography of innovation builds on both firm level and locational factors. This combination also allows for an increased understanding of the dynamics behind the emerging global innovation networks. However, further research is required for generalisation at the empirical level. For this purpose, looking into interrelationships of firm level, home economy, and host economy characteristic is relevant.

Emerging markets are different from the MNCs' home economies, wherefore MNCs tend to be takers rather than makers of institutional frameworks. The Chinese Government has devised policies to enhance the locational attractiveness of China very well, which so far has facilitated the evolution of China from being completely closed for foreign firms, to during the 1990s becoming the factory of the world, and today increasingly an attractive location for R\&D FDI, and for some industries even a hub for innovation. Still, although not influencing FDI policies in China, MNCs need the capabilities to interpret policies and their consequences, in particular in emerging markets. Generalising this to other emerging markets would be wrong and against the idea of a co-evolutionary framework. A second key finding of this article relates to MNC strategies. In order to access an emerging market, understanding the specific institutional and industrial dynamics and developments is highly relevant. Different institutional frameworks and combinations of O- and L-advantages are likely to lead to different trajectories in other locations. This needs further investigation.

The analysis of Danish MNC internationalisation showed no support for the argument that companies from small open economies are faster in internationalisation. On the contrary, looking at the FDI statistics of Danish FDI in China and FDI in China in general, the Danish investments were slightly delayed as compared to the milestones for overall FDI inflow in China. This was also the case in the four MNCs' trajectories into China. This indicates that, although Danish firms may be faster overall in internationalisation, this is indeed in the near-neighbouring countries where the liability of foreignness is limited. Locations in Asia, in this article, China needs more time for transformation of the firm. However, looking at how far these companies have evolved in China, this development and level of embeddedness is quite amazing. Still the companies face the challenges of developing network strategies and identifying the right external partners in China, developing tools for coordination of global projects at the project level, and developing tools for network optimisation and monitoring the consequences of the new innovation structure of the MNCs. Further in-depth firm-level studies into the consequences of this reorganisation of innovation for $\mathrm{MNC}$ innovation performance and overall competitiveness would be relevant.

\section{Acknowledgements}

I am grateful to Sino-Danish Center (SDC) for financial support of this research. Also my research assistant Mathias Sloth Andersen has provided immense support for this research. 


\section{References}

Archibugi, D. and Iammarino, S. (1999) 'The policy implications of the globalisation of innovation', Research Policy, Vol. 28, No. 2, pp.317-336.

Archibugi, D. and Michie, J. (1995) 'The globalisation of technology: a new taxonomy', Cambridge Journal of Economics, Vol. 19, No. 1, pp.121-140.

Benito, G.R., Larimo, J., Narula, R. and Pedersen, T. (2002) 'Multinational enterprises from small economies: internationalization patterns of large companies from Denmark, Finland, and Norway', International Studies of Management \& Organization, Vol. 32, No. 1, pp.57-78.

Blanchard, J-M.F. (2008) 'Harmonious world and China's foreign economic policy: features, implications, and challenges', Journal of Chinese Political Science, Vol. 13, No. 2, pp.165-192.

Buckley, P.J. and Ghauri, P.N. (2004) 'Globalisation, economic geography and the strategy of multinational enterprises', Journal of International Business Studies, Vol. 35, No. 2, pp.81-98.

Cano-Kollmann, M., Cantwell, J., Hannigan, T.J., Mudambi, R. and Song, J. (2016) 'Knowledge connectivity: an agenda for innovation research in international business', Journal of International Business Studies, Vol. 47, No. 3, pp.255-262.

Cantwell, J. (1995) 'The globalisation of technology: what remains of the product cycle model?', Cambridge Journal of Economics, Vol. 19, No. 1, pp.155-155.

Cantwell, J. and Mudambi, R. (2005) 'MNE competence-creating subsidiary mandates', Strategic Management Journal, Vol. 26, No. 12, pp.1109-1128.

Cantwell, J. and Piscitello, L. (2014) 'Historical changes in the determinants of competence creation in MNC subunits: the increasing role of international knowledge', Industrial and Corporate Change, Vol. 23, No. 3, pp.633-660.

Cantwell, J. and Zhang, Y. (2009) 'The co-evolution of international business connections and domestic technological capabilities: lessons from the Japanese catch-up experience', Transnational Corporations, Vol. 18, No. 2, p.37.

Cantwell, J. and Zhang, Y. (2011) 'Innovation and location in the multinational firm', International Journal of Technology Management, Vol. 54, No. 1, pp.116-132.

Cantwell, J., Dunning, J.H. and Lundan, S.M. (2010) 'An evolutionary approach to understanding international business activity: the co-evolution of MNEs and the institutional environment', Journal of International Business Studies, Vol. 41, No. 4, pp.567-586.

Coe, N.M., Dicken, P. and Hess, M. (2008) 'Global production networks: realizing the potential', Journal of Economic Geography, Vol. 8, No. 3, pp.271-295.

Costa, R.M., Bruno, M.A., Vasconcellos, E. and Junior, L.A.D.S. (2015) 'MNCs' subsidiaries in emerging countries driving internationalisation and innovation: a case study in Brazil', International Journal of Automotive Technology and Management, Vol. 15, No. 4, pp.381-400.

D’Agostino, L.M. and Santangelo, G.D. (2012) 'Do overseas R\&D laboratories in emerging markets contribute to home knowledge creation?', Management International Review, Vol. 52, No. 2, pp.251-273.

Dosi, G. (1982) 'Technological paradigms and technological trajectories: a suggested interpretation of the determinants and directions of technical change', Research Policy, Vol. 11, No. 3, pp.147-162.

Dunning, J.H. (1988) 'The eclectic paradigm of international production: a restatement and some possible extensions', Journal of International Business Studies, Vol. 19, No. 1, pp.1-31.

Dunning, J.H. (1992) Multinational Enterprises and the Global Economy, Addison-Wesley, Reading Mass.

Dunning, J.H. (2000) 'The eclectic paradigm as an envelope for economic and business theories of MNE activity', International Business Review, Vol. 9, No. 2, pp.163-190. 
Dunning, J.H. and Lundan, S.M. (2008) Multinational Enterprises and the Global Economy, Edward Elgar Publishing, Cheltenham.

Dunning, J.H. and Lundan, S.M. (2009) 'The internationalization of corporate R\&D: a review of the evidence and some policy implications for home countries', Review of Policy Research, Vol. 26, Nos. 1-2, pp.13-33.

Ernst, D. (2006) Innovation Offshoring. Asia's Emerging Role in Global Innovation Networks, East-West Center Special Reports, p.10.

Feenstra, R.C. (1998) 'Integration of trade and disintegration of production in the global economy', Journal of Economic Perspectives, Vol. 12, No. 4, pp.31-50.

Feinberg, S.E. and Majumdar, S.K. (2001) 'Technology spillovers from foreign direct investment in the Indian pharmaceutical industry', Journal of International Business Studies, Vol. 32, No. 3, pp.421-437.

Florida, R. (2002) 'The economic geography of talent', Annals of the Association of American Geographers, Vol. 92, No. 4, pp.743-755.

Florida, R. (2005) 'The world is spiky', The Atlantic Monthly.

Forsgren, M. (2013) Theories of the Multinational Firm: A Multidimensional Creature in the Global Economy, Edward Elgar Publishing, Cheltenham.

Freeman, C. (1995) 'The 'national system of innovation' in historical perspective', Cambridge Journal of Economics, Vol. 19, No. 1, pp.5-24.

Gassmann, O. and Han, Z. (2004) 'Motivations and barriers of foreign R\&D activities in China', $R \& D$ Management, Vol. 34, No. 4, pp.423-437.

Gereffi, G., Humphrey, J. and Sturgeon, T. (2005) 'The governance of global value chains', Review of International Political Economy, Vol. 12, No. 1, pp.78-104.

Haakonsson, S.J. (2012) 'The globalization of innovation in the Danish food industry: exploitation and exploration of emerging markets', Innovation and Development, Vol. 2, No. 2, pp.230-247.

Haakonsson, S.J. and Kirkegaard, J.K. (2016) 'Configuration of technology networks in the wind turbine industry: a comparative study of technology management models in European and Chinese lead firms', International Journal of Technology Management, Vol. 70, No. 4, pp.281-299.

Haakonsson, S.J. and Ujjual, V. (2015) 'Internationalisation of R\&D: new insights into multinational enterprises' R\&D strategies in emerging markets', Management Revue, Vol. 26, No. 2, pp.101-122.

Haakonsson, S.J., Jensen, P.D.Ø. and Mudambi, S.M. (2013) 'A co-evolutionary perspective on the drivers of international sourcing of pharmaceutical R\&D to India', Journal of Economic Geography, Vol. 13, No. 4, pp.677-700.

Herstad, S.J., Aslesen, H.W. and Ebersberger, B. (2014) 'On industrial knowledge bases, commercial opportunities and global innovation network linkages', Research Policy, Vol. 43, No. 3, pp.495-504.

Hobday, M. and Rush, H. (2007) 'Upgrading the technological capabilities of foreign transnational subsidiaries in developing countries: the case of electronics in Thailand', Research Policy, Vol. 36, No. 9, pp.1335-1356.

Hoskisson, R.E., Eden, L., Lau, C.M. and Wright, M. (2000) 'Strategy in emerging economies', Academy of Management Journal, Vol. 43, No. 3, pp.249-267.

Iammarino, S. and McCann, P. (2013) Multinationals and Economic Geography: Location, Technology and Innovation, Edward Elgar Publishing, Cheltenham.

Iammarino, S., Padilla-Pérez, R. and Von Tunzelmann, N. (2008) 'Technological capabilities and global-local interactions: the electronics industry in two Mexican regions', World Development, Vol. 36, No. 10, pp.1980-2003.

Iversen, M., Fellman, S., Sjögren, H. and Thue, L. (2008) Creating Nordic Capitalism: The Business History of a Competitive Periphery, Palgrave Macmillan, Hampshire. 
Jensen, P.D.Ø. and Pedersen, T. (2011) 'The economic geography of offshoring: the fit between activities and local context', Journal of Management Studies, Vol. 48, No. 2, pp.352-372.

Johanson, J. and Vahlne, J-E. (1977) 'The internationalization process of the firm - a model of knowledge development and increasing foreign market commitments', Journal of International Business Studies, Vol. 8, No. 1, pp.23-32.

Johanson, J. and Vahlne, J-E. (2009) 'The Uppsala internationalization process model revisited: from liability of foreignness to liability of outsidership', Journal of International Business Studies, Vol. 40, No. 9, pp.1411-1431.

Katzenstein, P.J. (1985) Small States in World Markets: Industrial Policy in Europe, Cornell University Press, New York.

Kogut, B. (1983) 'Foreign direct investment as a sequential process', in Kindleberger, C.P. and Audretsch, D. (Eds.): The Multinational Corporations in the 1980's, MIT Press, Cambridge, MA.

Kogut, B. (1990) 'International sequential advantages and network flexibility', in Bartlett, C.A., Doz, Y. and Herlund, G. (Eds.): Managing the Global Firm, pp.47-68, Routledge, New York.

Kogut, B. and Zander, U. (1993) 'Knowledge of the firm and the evolutionary theory of the multinational corporation', Journal of International Business Studies, Vol. 24, No. 4, pp.625-645.

Koza, M.P. and Lewin, A.Y. (1998) 'The co-evolution of strategic alliances', Organization Science, Vol. 9, No. 3, pp.255-264.

Kuemmerle, W. (1999) 'Foreign direct investment in industrial research in the pharmaceutical and electronics industries - results from a survey of multinational firms', Research Policy, Vol. 28, Nos. 2-3, pp.179-193.

Lewin, A.Y., Long, C.P. and Carroll, T.N. (1999) 'The coevolution of new organizational forms', Organization Science, Vol. 10, No. 5, pp.535-550.

Lewin, A.Y., Massini, S. and Peeters, C. (2009) 'Why are companies offshoring innovation? The emerging global race for talent', Journal of International Business Studies, Vol. 40, No. 6 , pp.901-925.

Li, Z. (2013) How Foreign Direct Investment Promotes Development: The Case of the People's Republic of China's Inward and Outward FDI, Asian Development Bank Economics Working Paper Series, No. 304.

Liu, J., Chaminade, C. and Asheim, B. (2013) 'The geography and structure of global innovation networks: a knowledge base perspective', European Planning Studies, Vol. 21, No. 9, pp.1456-1473.

Liu, Z. (2015) Do We Need Local Ownership Requirement for Foreign Direct Investment? Evidence from Chinese Firms, National University of Singapore, Singapore.

London, T. and Hart, S.L. (2004) 'Reinventing strategies for emerging markets: beyond the transnational model', Journal of International Business Studies, Vol. 35, No. 5, pp.350-370.

Long, G. (2005) 'China's policies on FDI: review and evaluation', in Moran, T.H., Graham, E.M. and Blomström, M. (Eds.): Does Foreign Direct Investment Promote Development, pp.315-336, Center for Global Development, Washington DC.

Madsen, T.K. and Servais, P. (1997) 'The internationalization of born globals: an evolutionary process?', International Business Review, Vol. 6, No. 6, pp.561-583.

Malik, O.R. and Kotabe, M. (2009) 'Dynamic capabilities, government policies, and performance in firms from emerging economies: evidence from India and Pakistan', Journal of Management Studies, Vol. 46, No. 3, pp.421-450.

Meyer, K.E. (2004) 'Perspectives on multinational enterprises in emerging economies', Journal of International Business Studies, Vol. 35, No. 4, pp.259-276.

Meyer, K.E. (2006) 'Global focusing: from domestic conglomerates to global specialists', Journal of Management Studies, Vol. 43 No. 5, pp.1109-1144. 
Moncada-Paternò-Castello, P., Vivarelli, M. and Voigt, P. (2011) 'Drivers and impacts in the globalisation of corporate R\&D: an introduction based on the European experience', Industrial and Corporate Change, Vol. 20, No. 2, pp.585-603.

Mudambi, R. (2007) 'Offshoring: economic geography and the multinational firm', Journal of International Business Studies, Vol. 38, No. 1, p.206.

Mudambi, R. (2008) 'Location, control and innovation in knowledge-intensive industries', Journal of Economic Geography, Vol. 8, No. 5, pp.699-725.

Oxelheim, L. and Ghauri, P. (2008) 'EU-China and the non-transparent race for inward FDI', Journal of Asian Economics, Vol. 19, No. 4, pp.358-370.

Park, B.I. (2016) 'The future journey of International Journal of Multinational Corporation Strategy', International Journal of Multinational Corporation Strategy, Vol. 1, No. 1, pp.1-17.

Patel, P. and Pavitt, K. (1992) 'The innovative performance of the world's largest firms: some new evidence', Economics of Innovation and New Technology, Vol. 2, No. 2, pp.91-102.

Peng, M.W., Wang, D.Y. and Jiang, Y. (2008) 'An institution-based view of international business strategy: a focus on emerging economies', Journal of International Business Studies, Vol. 39, No. 5, pp.920-936.

Pronina, M., Kuivalainen, O. and Torkkeli, L. (2016) 'Dynamic capabilities in MNCs: subsidiary international business competence in the Finnish-Russian context', International Journal of Multinational Corporation Strategy, Vol. 1, No. 2, pp.87-105.

Puck, J.F., Holtbrügge, D., Mohr, A.T., Lee, S-H. and Makhija, M. (2009) 'Beyond entry mode choice: explaining the conversion of joint ventures into wholly owned subsidiaries in the People's Republic of China', Journal of International Business Studies, Vol. 40, No. 3, pp.388-404.

Rugman, A.M. and Verbeke, A. (2005) 'Towards a theory of regional multinationals: a transaction cost economics approach', MIR: Management International Review, Vol. 45, No. 1, pp.5-17.

Santos-Paulino, A.U., Squicciarini, M. and Fan, P. (2014) 'Foreign direct investment, R\&D mobility and the new economic geography: a survey', The World Economy, Vol. 37, No. 12, pp.1692-1715.

Shan, W. and Song, J. (1997) 'Foreign direct investment and the sourcing of technological advantage: evidence from the biotechnology industry', Journal of International Business Studies, Vol. 28, No. 2, pp.267-284.

Shenkar, O. (1990) 'International joint ventures' problems in China: risks and remedies', Long Range Planning, Vol. 23, No. 3, pp.82-90.

Statistics Denmark (2008) International Sourcing: Moving Business Functions Abroad, June, Copenhagen.

Stratfor (2010) 'It's about to get more expensive for foreigners to do business in China', 1 December [online] from http://www.businessinsider.com/its-about-to-get-more-expensivefor-foreigners-to-do-business-in-china-2010-12 (accessed 13 October 2016).

Teece, D.J., Pisano, G. and Shuen, A. (1997) 'Dynamic capabilities and strategic management', Strategic Management Journal, Vol. 18, No. 7, pp.509-533.

Thompson, G.F. and Kaspersen, L.B. (2012) 'The globalization of the business sector in a small open economy: the case of Denmark and its wider implications', Socio-Economic Review, Vol. 10, No. 4, mwr036.

Vernon, R. (1966) 'International investment and international trade in the product cycle', The Quarterly Journal of Economics, Vol. 80, No. 2, pp.190-207.

Verspagen, B. and Schoenmakers, W. (2004) 'The spatial dimension of patenting by multinational firms in Europe', Journal of Economic Geography, Vol. 4, No. 1, pp.23-42.

Volberda, H.W. and Lewin, A.Y. (2003) 'Guest editors' introduction co-evolutionary dynamics within and between firms: from evolution to co-evolution', Journal of Management Studies, Vol. 40, No. 8, pp.2111-2136. 
Walmsley, T.L., Hertel, T.W. and Ianchovichina, E. (2006) 'Assessing the impact of China's WTO accession on investment', Pacific Economic Review, Vol. 11, No. 3, pp.315-339.

Wei, Y.H.D., Zhou, Y., Sun, Y. and Lin, G.C.S. (2012) 'Production and R\&D networks of foreign ventures in China: implications for technological dynamism and regional development', Applied Geography, Vol. 32, No. 1, pp.106-118.

Westney, D.E. (2009) 'The multinational firm as an evolutionary system', in Collinson, S. and Morgan, G. (Eds.): Images of the Multinational Firm, pp.117-144.

Whitley, R. (2009) 'The multinational firm as a distinct organizational form', in Collinson, S. and Morgan, G. (Eds.): Images of the Multinational Firm, Citeseer.

Zanfei, A. (2000) 'Transnational firms and the changing organisation of innovative activities', Cambridge Journal of Economics, Vol. 24, No. 5, pp.515-542. 